\title{
THE FUTURE OF SOCIAL CRIME CONTROL IN THE HATE SPEECH IN SOCIAL MEDIA WITH MEDIA LITERACY
}

\author{
Monica MARGARET* \\ Budi Luhur University, Indonesia \\ *monica.margaret@budiluhur.ac.id
}

\begin{abstract}
Many media develop and in the end make people not only as spectators or consumers of information but also as producers of information. Information technology is currently developing rapidly, quickly, easily, and very sophisticatedly, so that it becomes a necessity and lifestyle for the world community without exception, people in Indonesia are also affected by the development of information technology at this time. One aspect of technological development is the emergence of many social media sites such as Google or Mozilla Firefox and others, but the most popular among social media users include Facebook. The development of social media such as Facebook not only has a positive impact, but also has a negative impact, resulting in various types of violations and even crimes. Acts or crimes what needs serious attention is the crime of hate speech. Hate speech can be control by media literacy because its perspective that is used actively, when individuals access the media with the aim of interpreting the messages conveyed by the media. It is related to understanding the impact of communication, from advertising, ideas, to technology. By doing the media literacy, uses the media literacy approach as an effort to fight hate messages, through citizenship education and digital citizenship. One of its main objectives is to raise awareness about the political, social and cultural rights of individuals and groups, including freedom of speech and the responsibilities and social implications that arise.
\end{abstract}

Keywords: Media Literacy, Hate Speech, Social Control, Crime

\section{BACKGROUND}

\section{Social Control Culture}

Martindale (1978) suggested that the concept of social control was originally symbolized as the capacity of a group or society to self-regulate and to secure coherence and unity in social life in the earliest explanations in sociology since the late 19th century (Pasquire, Flores, Chaib-draa, 2006 ). Social control, in this sense (Hecter and Opp, 2001), is concerned with how social action is coordinated in a chosen direction or an emergent social order. Social control can be seen as the glue within society or as a broad representation of the mechanisms that are regulated and placed on community members (Pasquire, Flores, Chaib-draa, 2006).

Social control theory is fundamentally derived from the conception of human nature which proposes that there are no natural limits to basic human needs and wants. People will always want and seek further economic rewards and thus there is no need to seek special motives for engaging in criminal activities. Humans are born free to break the law and will only refrain from doing so under certain circumstances (Burke, 2009). According to Brown, Esbensen and Geis (2010), social control is a theory that revolves around the process of individual socialization. In this theory, the tendency to commit a crime or deviate is a function of the social process assumed or described.

Control Theories represents a contrasting approach to approaches in other theories, although the similarities are classified as explaining social processes. Each variation of the control perspective rests on the premise that, if left alone, individuals will pursue self-interest rather than societal interest. Only by intervening and nurturing individuals into controlled social existence can they be shaped into conformity.

The definition of social control from the sociological dictionary states that social control is defined to include all social processes, institutions and methods that result in (or efforts to produce) conformity or regulate the behavior of individuals and collectives of its members. The research report written by Blower and Nagaraj (2010) considers social control in terms of its role in securing compliance with norms by preventing, prosecuting, tackling and imposing non-compliance sanctions. It focuses on deliberate, planned programming and responses by state and corporate authorities to activities, behaviors or statuses that are deemed criminal, problematic, undesirable, harmful or troublesome. Anchor of a form of social control is an institution that deals with crime, danger, delinquency and other social problems.

Susanne Karstedt and Kai-D Bussmann (1999) in their book Social Dynamics of Crime and Control mention, in a changing society, the nature of crime also changes rapidly following changes that occur in society. The pattern of crime also changes with changes in people's lifestyles. In line with what was stated by Sunarto (2000) that the crime contained in society develops along with the development of society itself because crime is a product of society and this needs to be overcome. But the fact that crime is changing means we all need to renew the way we think about crime prevention (Theresa, 2016).

\section{Hate Speech Part of the Development of Social Space Dimensions (Globalization, Technology, Media)}

In the modern era like today, various things can be done by humans. Moreover, with the advancement of technology in human life, many things that previously could not be done easily become easier. For example in disseminating information to the general public. Before the development of technology to what it is today, mass dissemination of information could only be done by certain people. It can even be said that only a few organizational 
institutions can disseminate information to the public. But along with the development of information technology in the era of globalization (Sarah Novita Diah, 2018).

More and more people can become disseminators of information to the wider community. Many media develop and in the end make people not only as spectators or consumers of information but also as producers of information. Ease of accessing communication due to the development of technology, also of course has a big influence on developments in socializing. For example, social media, media that can be accessed online on line or connected to the internet and also the breadth of reach makes it easy for the public to communicate (Sarah Novita Diah, 2018).

Information technology is currently developing rapidly, quickly, easily, and very sophisticatedly, so that it becomes a necessity and lifestyle for the world community without exception, people in Indonesia are also affected by the development of information technology at this time. One aspect of technological development is the emergence of many social media sites such as Google or Mozilla Firefox and others, but the most popular among social media users include Facebook, Twitter, BBM, WhatsApp, Instagram, and many others (Muklis Dinillah, 2018).

Facebook has been transformed into the largest social networking site today. Users or Facebook users worldwide have reached 900 million to 1 billion users. Therefore, it is no stranger that on Facebook there are many online crimes (cyber crime). Criminals in the internet sector try to take advantage of this condition by spreading hate speech that can be reached by many people in a short time. Even the people who are reached can be forwarded by other people, having a "share" or "like" or "repost" feature or the like that makes it easy for each user to redistribute the distributed content (Lidya, 2018).

The development of social media not only has a positive impact, but also has a negative impact, resulting in various types of violations and even crimes. Acts or crimesWhat needs serious attention is the crime of hate speech. Because hate speech is a crime committed by a group or individual in the form of provocation, incitement, commenting on the physical shortcomings of others (body shaming) or insults to other individuals or groups in various aspects such as skin color, race, gender, sexual orientation, disability., citizenship, religion, etc. (R. Soesilo, 1995). Aspects in hate speech can include many things, such as SARA and hate speech, which is carried out using media in the form of banners, banners during campaigns, using mass media and electronic media.

According to the Head of the Public Information Bureau, Brigadier General Mohammad Iqbal, the National Police has detected hundreds of provocative content containing hate speech referring to ethnicity, religion, race and intergroup (SARA), hoaxes (fake news), and hate speech throughout 2018 (Muklis Dinillah, 2018). The Director General of Informatics Applications (Aptika) of the Ministry of Communication and Information (Kominfo) Semuel Abrijani Pangerapan said that 2,018 cases of hate speech and slander have been resolved in 2017, and 1,307 cases have not been resolved. The most types of hate speech crimes were insults as many as 1,657 cases, followed by the types of acts of fun acts as many as 1,224 cases, then the least types were cases of defamation as many as 444 cases.

Hate speech has encouraged the spirit of cursing, cursing, and hating each other. If this phenomenon is left unchecked, then this country will be increasingly in danger of division and social conflict (Pranamya Dewati, 2017). This data is actually quite surprising, when viewed from the fact that the ITE law was updated in 2016. One of the hate speech cases that is still being discussed today is the hate speech committed by Jon Riah Ukur Ginting or commonly called Jonru Ginting. Jonru was reported by Muannas Alaidid because his post was considered to contain hate speech and racial intolerance and violated article 27 paragraph 3 article 28 paragraph 2 of the Republic of Indonesia Law number 19 of 2016 concerning ITE (Kumparan News, 2017). Then on September 28, 2017, Jonru Ginting was declared a suspect.

The importance of understanding between hate speech and freedom of speech is related to the guarantee of the right to freedom to express thoughts and or opinions in writing, verbally, and in expression as guaranteed and regulated in the 1945 Constitution of the Republic of Indonesia (UUD RI 1945). In addition to this guarantee of human rights, assessing and understanding an action that can be included in hate speech or not, so that the purpose of the conception of hate speech is not misunderstood by the public or law enforcement. Thus, law enforcement for hate speech crimes can be carried out professionally and in accordance with human rights (HR) guidelines or principles. Every human being needs to understand how to use social media wisely.

\section{METHODS}

This paper was conducted with the qualitative descriptive methodology as it descrbes explanations on how the technology development can be fit as a media for crime, in this part it is a hate speech happened in social media. By collecting the main data from primary and secondary data, this research was doing. Many secondary data by doing study literatures also conduct in this research. After all the data needed was collected through to the significance of this research, then researcher try to analyse with the approriate data and theory.

\section{RESULTS AND DISCUSSION}

Surveillance by Staples on Hate Speech by Jonru Ginting on Social Media in Postmodern

As stated by Staples (2013) in his book on surveillance in postmodern, that postmodern surveillance 
tends to be systematic, methodical, and automatic in its operation. In fact, the role played by highly efficient digital databases is very important, this is related to the hate speech that Jonru Ginting did some time ago. Departing from an understanding of kHate speech crimes are communications carried out by groups or individuals that are pitched and take the form of provocation, insults, or incitement to groups or individuals in various aspects such as skin color, race, ethnicity, gender, sexual orientation, disability, nationality, religion. , etc. In a legal sense, hate speech is behavior, speech, performance, or writing that is prohibited because it can lead to prejudice or acts of violence, either on the part of the perpetrator of the statement or the victim of the act of hate speech (Widayati, 2018). Hate speech crimes cannot only be considered as ordinary crimes. The crime of hate speech in the context of the interaction of the majority or dominant community group with the minority. Hate speech crimes come in various forms, usually appearing to oppose the presence of other groups. In the phenomenon of hate speech crimes, there are many factors that cause crimes such as stigmatizing certain groups that are considered a threat to their group. In the process of meeting these needs, actors often even consider rationally and make decisions based on their limitations, abilities, and the availability of information related to the target (Cornish Clarke, 1997).

The ability to make decisions made Jonru Ginting start criticizing the government in early 2012, this is what causes him to make hate speech is a factor that comes from within the individual, namely internal factors consisting of the psychological state of the perpetrator, namely emotional power (Febriyani, 2018). These factors are very influential on the perpetrators who commit crimes, especially the psychological state of the individual, namely the uncontrolled excessive emotional power.

Jonru was reported by Muannas Alaidid because his post was considered to contain hate speech and sara and violated Article 27 paragraph 3, Article 28 paragraph 2 of the Republic of Indonesia Law Number 19 of 2016 concerning ITE (Kumparan News, 2017). Then on September 28, 2017, Jonru Ginting was declared a suspect. There are seven controversial statements by Jonru on social media (Pranamya Dewati, 2017), namely:

1. "There is no Ministry of Religion in the Jokowi-JK Cabinet. Alright! More and more Anti-Islam disguises are exposed! Even though he used to claim to love Islam, even though photos of praying were distributed everywhere, even though he left for Umrah after the campaign, even though... that's it!"

2. "It only takes THREE simple logic to find out the MISTAKES of Islam Nusantara (This is a repost of the previous status, I made a more suitable picture, with the hope of being shared by all of your friends. Hopefully it will be useful for the spread of da'wah, in order to combat heretical sects." which can damage our aqidah and Islamic faith).
3. "Our question is: Why is the calendar from the same supplier now all Chinese? Whereas for the calendars of previous years, the calendar system is still Christian, Javanese and Islamic. Why since the Jokowi era, Chinaization has become more rampant? looks like the yuan. What's wrong with Indonesia?"

4. "Let's fight the hijab ban in Bali. \#Indonesia TanpaDiscrimination"

5. "Is the tragedy of the elevator crash in Blok M Square an attempt to kill Mr. Anies Baswedan, because someone doesn't want him to be the winner of the 2017 DKI Pilgub? Wallahualam,"

6. "Take an economic plane to make it look populist, even though the group of jockeys to Singapore consisted of the Paspampres troops, palace reporters (Street Tunesm Reuters, Ap, Detik, Kompas etc.) all the groups were brought with all their equipment from Jakarta, so the contents of the Garuda plane just a group of jockeys. Therefore, the flight schedule was chaotic and many airplane passengers were disappointed because of the schedule delay."

7. "Jokowi is the only presidential candidate whose parents are not yet clear. It's strange! For a position as important as the PRESIDENT, so many people believe in people whose origins are unclear."

In the first sentence that Jonru said regarding there is no ministry of religion in the Jokowi-JK Cabinet, after the election of Jokowi-JK as President and Vice President, Jonru issued a controversial statement. In his Facebook post on September 16, 2014, Jonru stated that there was no Ministry of Religion in the Jokowi-JK Cabinet. This statement is certainly not proven because in the cabinet composition announced by Jokowi on October 26, 2014, Lukman Hakim Saifuddin's name was listed as Minister of Religion. The second sentence says that Islam Nusantara is heretical. Islam Nusantara is a term echoed by the Nahdlatul Ulama (NU) community organization. This term reap the pros and cons of a number of circles. One of them, Jonru, voiced his disagreement with 'Islam Nusantara'. In his post dated August 13, 2015, Jonru said that it only takes three simple logics to find out the error of 'Islam Nusantara'. Jonru also accompanied his post with a picture of Ulil Abshar Abdalla and Zuhairi Misrawi, who are said to be activists of the Liberal Islam Network (JIL). This post sparked controversy considering that NU is the largest Islamic organization in Indonesia with tens of millions of followers.

In the third sentence, Jonru discussed the rampant Chinaization in President Jokowi's cabinet. In his Facebook post on December 26, 2016, Jonru shared his experience getting calendars from his subscription store. What surprised him was that the calendar system changed to the Chinese calendar. He also uploaded a calendar photo as proof that what he wrote was not a hoax or hoax. At the end of his post, Jonru included a question about 
the Chinaization that was rampant in the Jokowi era. Furthermore, the fourth, Jonru said there is a ban on the use of the hijab in Bali. Jonru through his Twitter account dated August 14, 2014 wrote about the ban on the hijab in Bali. This tweet immediately sparked controversy. A number of partiesthink that what Jonru said could trigger division considering Bali inhabited by the majority of people who are Hindus. Not a few have criticized that Jonru have spread lies. After it was discovered that the issue was not true, Jonru deleted his post.

The fifth sentence, Jonru conveyed hate speechthe relationship between Anies Baswedan and the falling elevator. On Friday 17 March 2017, an elevator at Blok M Square Mall crashed. Incident this left a number of people injured. When the fateful incident occurred, it was known that the Governor of DKI-elect Anies Baswedan was at the Nurul Iman Mosque, on the 7th floor of Blok M Square. In response to this, Jonru made a kind of analysis through his Facebook account. Jonru explained the reason an elevator could fall. He believed that it was impossible for the elevator to fall because of the overload. Quoting his friend, Jonru said that there were only two causes for the elevator to fall, namely the rope was loose or it was loosened on purpose. At the end of his post, Jonru wrote a question regarding Anies' whereabouts and the elevator crash. The sixth post discussesregarding President Jokowi and economy class planes. In November 2014, President Joko Widodo and his wife Iriana Widodo went to Singapore to attend the graduation of their youngest son Kaesang Pangarep. The departure of Jokowi and his wife then became a conversation because they used Garuda Indonesia's economy class. Jokowi said his departure to Singapore was a family matter so there was no need to use state facilities. What Jokowi did got the attention of netizens. Not wanting to be left behind, Jonru also responded to Jokowi's departure with this economic plane. The last post which became one of the most crucial hate speeches at that time wasrelated to parents President Joko Widodo. Ahead of voting day in the 2014 General Election, Jonru wrote on Facebook that Jokowi is the only presidential candidate who is not yet clear who are his parents. Many people say that Jonru lied and slander. Jonru himself, recently in one of the shows on private television confirmed that the post was indeed written by him.

Problem violation or crime of defaming another person, slandering, blaspheming and an unpleasant act is an act that violates the law for disturbing and violating the rights of others. This act is not only can be done directly with words in public but also lately this is often done in cyberspace or social media, because in cyberspace people feel freedom in terms of expressing opinions or criticizing someone who considered not to violate the law and safe because they do not have direct physical contact with other people.

The development of technology followed by the development of social media as a facility or means to express thoughts so that it can be conveyed by many people is a factor that influences Jonru Ginting to carry out his activities (Meri Febriyani, 2018). With a very large influence, Jonru Ginting can provide information to the public quickly. The shift in the topic of the conversation will arise due to the user's lack of understanding of the impact of the message conveyed, especially if it turns out that he does not fully understand the content of the message (Satria Kusuma and Djuara P. Lubis, 2016). The information that appears will affect human behavior, or words can influence humans, even human opinions.

The main opinion of the Neutralization Theory, that someone will learn to neutralize the morals that control human behavior, then commit deviant behavior. In addition, this theory explains how a person commits deviance, and the way a person engages in deviant behavior. Neutralization theory emphasizes the learning process of young people to rationalize deviant behavior that is carried out so that it is expected to deceive the workings of social values and norms in society (Harto Djanggih and Nurul Qamar, 2018).

The next point, Staples (2013) explains related meticulous rituals of powerwith his thesis that this bodily life is shaped, manipulated, and controlled by a series of ongoing practices that shape our daily lives as workers, consumers, and members of society.Jonru Ginting as the perpetrator of hate speech who has been ensnared in the ITE Law Article 28 paragraph 2 for committing hate speech, insists that he has not done anything wrong for his actions and Jonru Ginting believes that his reporting to the police is only because of the heated political situation. Jonru Ginting has a very big influence and also has a rational choice to carry out activities, he stated that the treatment is carried out consciously and understands the limitations of ethical norms in society to meet needs such as money, status, sexual desire, and self-actualization. Jonru Ginting, aware of applicable ethics and laws.

In the process of meeting these needs, actors often even weigh rationally and make decisions based on their limitations, abilities, and the availability of information related to the target (Cornish and Clarke, 1997). It is assumed that human behavior is controlled by rational thoughts. This theory assumes that most people, most of the time, when doing something actions are controlled by good thoughts, but why do people who generally have good thoughts commit deviant actions or commit crimes. Jonru Ginting's initial goal in creating his Facebook fanpage was to criticize the government without any intention to spread hatred against the government.

A third characteristic of postmodern ritual relates to shifts in the location of social supervision and control. Since the early nineteenth century, our primary method of dealing with lawbreakers, those considered insane, deviant, criminal, and even the poor, has been to isolate them from the everyday life of society - as in the case of mental disorders. asylums, orphanages, modern prisons, and poor houses. 
But the kind of practice I'm most concerned with here tries to impose a framework of accountability on individuals in everyday life. Although, obviously, removing the most "troublesome" people from society is still a significant means of formal social control (Staples, 2013).

The freedom to use social media is not accompanied by responsibility by some netizens. Many actually use this freedom to do hate speech, cyberbullying, and the like (Fakhry, M. Chairul, 2018). Ethics in the online world today needs to be enforced to prevent even greater crimes and violations, considering that the online world has become an important part of communication and information infrastructure, especially more and more parties are abusing cyberspace to spread their displeasure over something that is wrong. concerning ethnicity, religion and race.

\section{Existing Rules in Controlling Hate Speech in Indonesia}

Seeing the rise of hate messages in Indonesia, the Government through the police (Polri) issued a special circular threatening the perpetrators of hate-spreading. In the Circular Letter (SE) of the National Police Chief Number SE/06/X/2015, it is stated that the issue of hate speech is getting more attention from the public, both nationally and internationally along with the increasing concern for the protection of human rights (HAM). In Number 2 letter (f) SE, it is stated that "hate speech can be in the form of criminal acts regulated in the Criminal Code (KUHP) and other criminal provisions outside the Criminal Code. controlling hate messages. Legal sanctions are more focused on upstream areas, namely those who produce hate messages. In the logic of supply and demand

The importance of understanding between freedom of speech and hate speech is related to the guarantee of the right to freedom of expression and opinion orally, in writing, and in expression as regulated and guaranteed by the 1945 Constitution of the Republic of Indonesia (UUD RI 1945). In addition to this guarantee of human rights, understanding and assessing an action that can be classified as hate speech or not, aims to prevent the conception of hate speech from being misunderstood, both by law enforcement and the public. Thus, law enforcement against violations of the prohibition on hate speech can be applied professionally in accordance with human rights principles.

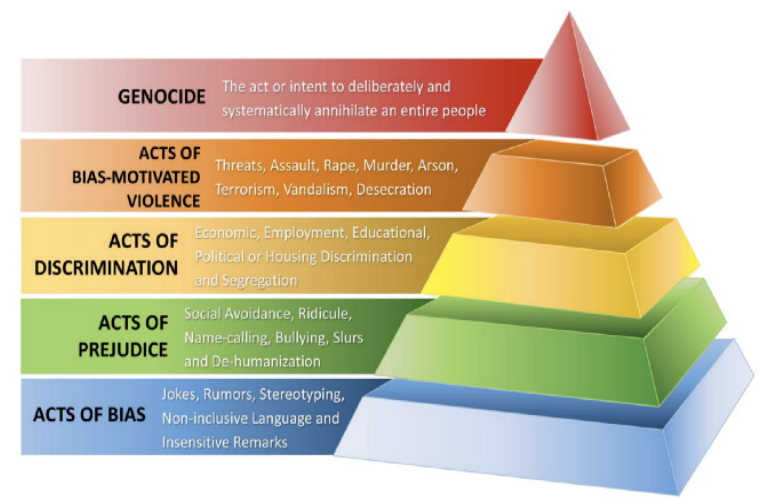

Picture 1. Pyramid of Khate

Source: adl.org.
Examples of hate speech cases conducted by Jonru Ginting in his posts on social media facebook are at the level of acts of bias-motivated violence, especially in cases that contain threats, attacks; also at the level of acts of discrimination that smells of SARA, politics, economics; at the level of acts of prejudice such as examples of expressions about humiliation, bullying and de-humanization as well as at the level of bias related to stereotypes and rumors.

\section{Media Literacy as a Form of Crime Social Control}

Staples (2013) develops new ways to control and "monitor" various problematic individuals and deviants through a growing network of "community correction" programs; the governing body for welfare, health, and social services; as well as in schools and other community institutions. And new developments in forensic, medical, and computer science and information generated by research and development companies, universities, and the military/security industrial complex - creating further, more flexible, and more efficient ways to make this happen. For example, done with media literacy.

Media literacy in Indonesia is better known as Media Literacy. James Potter (2001: 5) in his book entitled "Media literacy" says that media literacy is a perspective that is used actively, when individuals access the media with the aim of interpreting the messages conveyed by the media. It is related to understanding the impact of communication, from advertising, ideas, to technology (Folkert \& Lacy, 2004: 8).

Allan Rubin (in Baran \& Davis, 2003:375) offers three definitions of media literacy: First, from the National Leadership Conference on Media literacy, namely the ability to access, analyze, evaluate and communicate messages. Second, from a media expert, Paul Messaris, namely knowledge of how the media functions in society. Third, from mass communication researchers, Justin Lewis and Shut Jally, namely an understanding of cultural, economic, political and technological limitations on the creation, production and transmission of messages. Rubin also added that these definitions emphasize specific knowledge, awareness and rationality, namely the cognitive process of information. Its main focus is the critical evaluation of the message. Media literacy is an understanding of the sources and communication technology, the codes used, the messages generated and the selection, So, media literacy focuses on the individual as the party that produces, reproduces, or consumes messages. In the context of online media, this emphasis on individuals becomes more strategic, because the main communication actors are in the online realmare individuals (netizens). As with social media, the key to discourse lies with the owners of social media accounts. UNESCO (Gagliardon, 2015) itself uses the media literacy approach as an effort to fight hate messages, through citizenship education and digital citizenship. One of its main objectives is to raise 
awareness about the political, social and cultural rights of individuals and groups, including freedom of speech and the responsibilities and social implications that arise.

Citizenship education concerns regarding hate messages include knowledge and skills to identify hate messages, thereby enabling individuals to counter hate messages. One of the challenges today is adapting these goals and strategies to the digital world, providing not only the arguments, but also the technological knowledge and skills that citizens may need to neutralize online hatred. A new concept of digital citizenship is being proposed by several organizations that combines the core goals of media and information literacy, aims to develop technical and critical skills for consumers and media producers, and which connects them with ethics and civil rights.

\section{CONCLUSION}

In addition to the structural approach through regulation, cultural efforts through increasing media literacy are relevant to do. This media literacy focuses on the empowerment of netizens in responding to hateful messages in the online realm. Netizens with high media literacy are not only aware of ethics but also have constructive skills in receiving, producing and reproducing messages. Hate speech then can be controlled and prevent by doing the media literacy.

\section{REFERENCES}

Ariyanti, H. (2018). 90 Percent of Young People in Indonesia Use the Internet for Social Media. Accessed from:https:/www.merdeka.com/

Blower, E., Nagaraj, VK. (2010). Modes and Patterns of Social Control: Implications for Human Rights Policy. International Council on Human Rights Policy. Geneva, Switzerland.

Brown, SE., Esbensen, F-A., and Geis, G. (2010). Criminology: Explaining Crime and Its Context 7th Ed. Matthew Bender and Company, Inc., Ohio.

Burke, RH. (2009). An Introduction to Criminological Theory 3rd Ed. Willan Publishing. Canada.
David, L. (2013). The Effect of Technological Developments in Human Life. Accessed from: https://www.liputan6.com.

Djanggih, H. and Qamar, N. (2018). Application of Criminological Theories in Combating Cyber Crime. Volume 13 (1).

Febriyani, M. (2018). Analysis of Factors Causing Perpetrators of Hate Speech in Social Media. Faculty of Law, University of Lampung Bandar Lampung.

Gagliardon, et al. (2015). Countering Online Hate Speech. Paris: UNESCO Publishing

Janowitz, M. (1975). Sociological Theory and Social Control. American Journal of Sociology, Vol. 81 (1). The University of Chicago Press.

Omoyibo, KU. and Obaro, OA. (2012). Applications of Social Control Theory: Criminality and Governmentality. International Journal of Asian Social Science. Volume 2 (7). Faculty of Social Sciences University of Benin, Nigeria.

Nasrallah, R. (2015). Social Media. Bandung: PT Pemuda Rosdakarya.

Pasquier, P., Flores, R., Chaib-draa, B. (2006). An Ontology of Social Control Tools. International Joint Conference on Autonomous Agents and Multi Agent Systems (AAMAS). ACM Press, Hakodate, Japan.

Potter, J. (2001). Media Literacy. London: Sage Publications

Staples, WG. (2013). Everyday Surveillance: Vigilance And Visibility In Postmodern Life. Rowman \& Littlefield.

Theresa, Hon Rt. (2016). Modern Crime Prevention Strategy. Home Office. Design 02. London.

Widayati, L. S. (2018). Hate Speech: Definition and Prohibition Limits. Info Singkat. Volume X. No. 06. March 